\title{
HEAVY METALS IN THE SOIL OF POTENTIAL TOBACCO PRODUCTION LOCATIONS IN VRANJE VALLEY
}

\author{
UDC 546.3/.9:631.453:633.71(497.11Vranje)
}

\author{
Tatjana Golubović ${ }^{1}$, Milica Arsić², Srđan Arsićc \\ ${ }^{1}$ University of Niš, Faculty of Occupational Safety in Niš, Niš, Serbia \\ ${ }^{2}$ Elementary School Dositej Obradović, Vranje, Serbia \\ ${ }^{3}$ Elementary School Radoje Domanović, Vranje, Serbia
}

\begin{abstract}
Before the change of the ownership of the Vranje Tobacco Industry, there had been a large scale tobacco production in the valley of Vranje. The number of tobacco growing households has declined significantly over the last 15 years, despite the good potential of agricultural land for growing this crop. Given the fact that the quality of tobacco depends on the conditions under which it is grown, above all on the soil quality, it is very important to be familiar with the soil composition and the presence of potential pollutants in soil, as well as the mechanisms of their transmission to the plant. Pollutants in agricultural land originate from natural and anthropogenic sources. Significant anthropogenic sources of soil pollutants are agricultural production (organic fertilizers, pesticides, etc.) and road transport. When it comes to tobacco quality, one of the most important groups of pollutants is heavy metals. Mineral and organic fertilizers, as well as pesticides often contain heavy metals. Considering the above facts, the aim of this paper was to determine and analyze the concentration of heavy metals such as $\mathrm{Pb}, \mathrm{Cd}, \mathrm{Cr}, \mathrm{Cu}$, $\mathrm{Mn}, \mathrm{Zn}$ and $\mathrm{Ni}$ in the soil of the villages Neradovac, Cukovac and Surdul, which are considered as potential sites for tobacco production. The surveys covered two periods, 2005 and 2018 (the analysis of soil) and 2005 (the analysis of tobacco). A comparative analysis of the results showed that the concentrations of heavy metals at the examined locations in soil and tobacco sampled in 2005, as well as the concentrations of heavy metals in soil sampled in 2018, were below the maximum allowable and remediation values. Because the remediation values of pollutants and hazardous substances in the soil are the values, which, if exceeded degrade the level of safety, it can be concluded that these values were not exceeded in either of the analyzed samples and that the soils were potentially safe to use with the additional tests and the necessary limitations in operating mode. Also, the chemical composition of the soil in these areas indicated that the values of the tested parameters were within the optimal values for the growth and development of plants without a negative impact, which again confirms the assumption that these localities are suitable for tobacco production.
\end{abstract}

Key words: heavy metals, soil, tobacco, pollution

Received April 19, 2020 / Accepted May 3, 2020

Corresponding author: Tatjana Golubović

Faculty of Occupational Safety in Niš, Čarnojevića 10a, 18000 Nišs, Serbia

E-mail: tatjana.golubovic@znrfak.ni.ac.rs 


\section{INTRODUCTION}

Soil is one of the most important natural resources. There is a dynamic equilibrium between soil and other spheres of the environment, which creates the conditions for the survival of humans and other organisms. Soil, together with water and air, is considered to be a renewable natural resource. However, given the limited total quantity and extremely slow process of production, as well as continuous pollution and irrational use, soil should be considered a limited, i.e. conditionally renewable natural resource.

The accelerated human population growth, the uncoordinated economic development, and the capacity of the biosphere cause the changes on Earth that can seriously endanger human survival. In this situation, the optimal use of land and its resources are the condition for the survival of present and future generations. In Serbia as well as all over the world, agricultural land is severely threatened since it is a subject to different forms of humaninduced degradation [1].

Agricultural production is one of the most prominent anthropogenic sources of soil pollution. The uncontrolled, excessive use of artificial fertilizers and pesticides often affects the production capacity of agricultural land, as well as the quality of crops. The most polluting substances of agricultural land include heavy metals, pesticides and mineral fertilizers [2-4].

The steady increase in population and the rise in standards have led to an increase in the number of motor vehicles whose exhausts have a negative impact on air quality. The consequence of this is a disturbed ecological balance having in mind that air pollution can significantly hurt the soil quality.

The behaviour of heavy metals in soil, whether generated by the process of pedogenesis or derived from anthropogenic sources, depends on several factors that affect their dynamics, and therefore the distribution and accessibility of plants. Soils vary depending on their limited capacity for holding heavy metals, and the significant factors which influence soil such as $\mathrm{pH}$ value, the adsorption capacity of total ions, the presence of organic matter, redox potential, etc. [5-9].

Tobacco (Nicotiana tabacum L.) is an industrial plant grown in about 100 world countries. According to the United Nations Food and Agriculture Organization (FAO), the world's largest producer is China, with more than $35 \%$ of total production $[10,11]$. This crop is grown on a less fertile soil, so special attention should be paid to proper mineral nutrition in order to have high quality and economically viable yields. Higher production of tobacco biomass is influenced by optimal concentrations of macronutrients, such as nitrogen, phosphorus and potassium. Apart from these, the concentration of heavy metals in soil has a significant impact on the yield and quality of tobacco [12-15].

The part of the European route E-75, the section between Belgrade and Preševo, goes through the Vranje Valley, which is considered a significant agricultural area (until recently, widely recognized for tobacco production). As a consequence, this could be a significant source of soil pollution by heavy metals.

Starting from the stated facts, the aim of this paper was to determine the concentrations of heavy metals and to analyze the chemical composition of the soil in the selected sites of the Vranje Valley, in order to justify the possibility of tobacco production at the given locations. 


\section{MATERIALS AND METHODS}

\subsection{Study area}

For the purposes of the survey, soil and tobacco were sampled from three locations of agricultural land, shown in Figure 1.

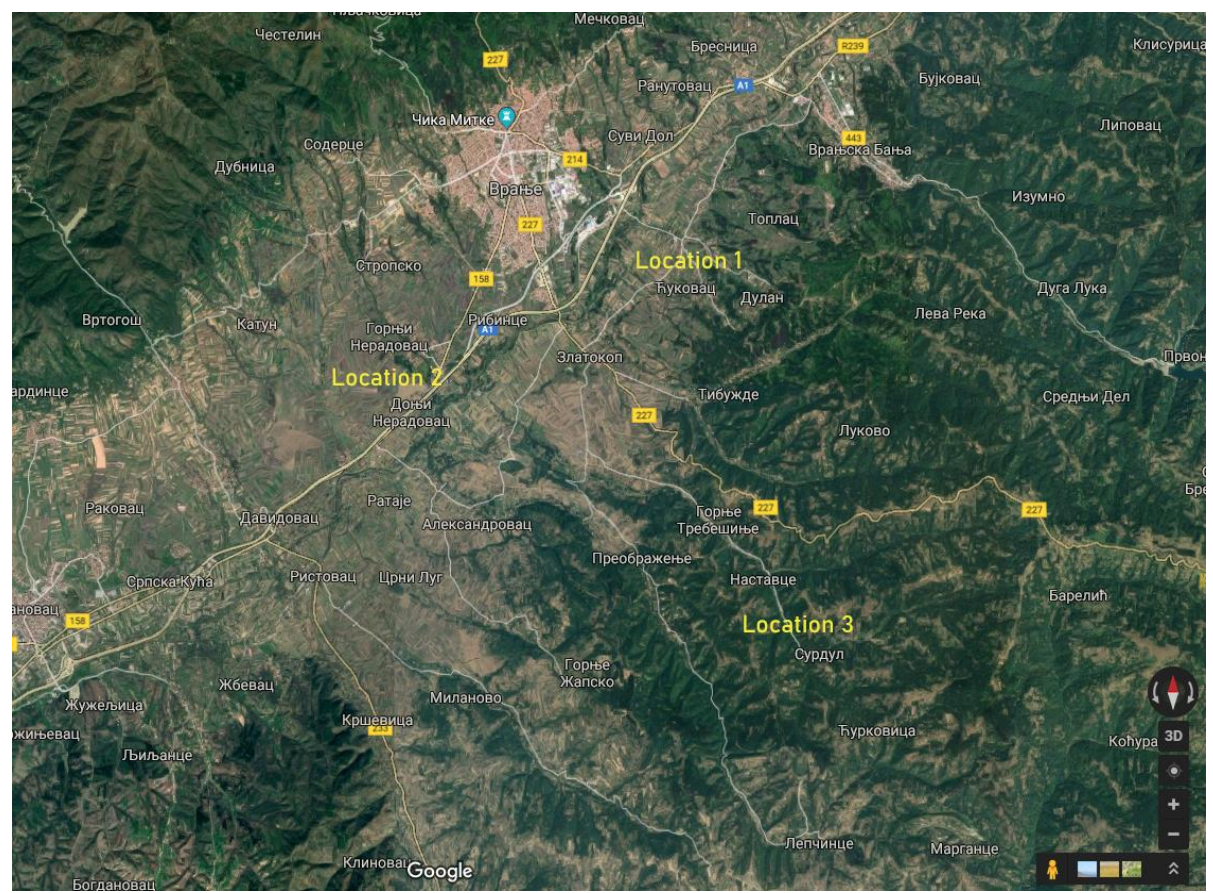

Fig. 1 The position of examined locations

Agricultural district of Ćukovac village - the area marked on the map with number 1; Agricultural district of Neradovac village - the area marked on the map with number 2;

Agricultural district of Surdul village - the area marked on the map with number 3.

Ćukovac is a village located near Vranje. It is located east of the city and is $5 \mathrm{~km}$ away from the highway. The village is located at an altitude of 499 meters above sea level. The inhabitants are predominantly employed in agriculture.

Neradovac is a lowland village near the South Morava, west of Vranje. It is located about $6 \mathrm{~km}$ from the city. The village is located at an altitude of 633 meters above sea level and near two roads - the old, main road and the newly built E-75 motorway. Given the fact that the village is rich in intensively cultivated arable land, we acknowledged the use of mineral fertilizers and pesticides.

Surdul is a village $22 \mathrm{~km}$ away from Vranje. It is a typical mountain village, located at an altitude of 905 meters above sea level. It occupies a large area with a lot of distanced settlements (mahallas). The village has about forty inhabitants who mainly work in agriculture, less in livestock breeding. Much of the area of this village is covered 
by mixed beech-oak forest, slightly fewer meadows, and the smallest part consists of arable land. Demographic growth is negative, so the village is slowly dying away. There are no asphalt roads near the village, no factories, so this location is considered unpolluted (control) $[16,17]$.

\subsection{Soil and plant sampling}

Soil samples $(0.5-1 \mathrm{~kg})$ were first ground and mixed. Subsequently, the samples were spread on thin-layer papers, the impurities were removed and then dried for 2-3 days until air-dry. The analyses were performed with air-dried samples, ground and sieved through a $1 \mathrm{~mm}$ sieve.

The sachets, which were placed in bags together with the average soil samples, contain the following data: place and time of sampling, depth to which the sample was taken (0-30 $\mathrm{cm}$ ), name and size of the plot, previous crops and subsequent crops.

In addition to the above data, all the information relevant for the interpretation of the results of chemical analysis and making recommendations for land use (the information about calcification, humidification, fertilization with mineral fertilizers, the use of pesticides) have been given here.

The plant and soil material were both sampled at the same location. After sampling, leaf samples were washed to remove any adhering soil particles and rinsed with distilled water, after which they were dried at $75^{\circ} \mathrm{C}$ for $12 \mathrm{~h}$ and ground.

The analyses of plant material and soil were made at the Public Health Institute in Vranje and the Agricultural Expert Service "Vranje" D.O.O. [18].

\subsection{Determining soil $\mathrm{pH}$}

Active and exchangeable acidity were measured using an electric $\mathrm{pH}$ meter.

Active acidity ( $\mathrm{pH}$ in $\mathrm{H}_{2} \mathrm{O}$ ) was determined for the suspension of soil with distilled water.

Preparing suspension for determining $\mathrm{pH}$ in $\mathrm{H}_{2} \mathrm{O}$. We put $10 \mathrm{~g}$ of air-dry soil in a 100 $\mathrm{ml}$ beaker and added $25 \mathrm{ml}$ of distilled water. The contents in the beaker were stirred using a glass stirring rod and let stand for about 30 minutes (during this time, it was stirred several times). Subsequently, the $\mathrm{H}^{+}$ion concentration was measured by immersing the doublejunction electrode in the suspension. Before the measurement, the $\mathrm{pH}$ meter was adjusted using standard solutions.

Exchangeable acidity $(\mathrm{pH}$ in $\mathrm{KCl}$ ) was determined for soil suspension with $1 \mathrm{M}$ solution of $\mathrm{KCl}$.

Preparing suspension for determining $\mathrm{pH}$ in $\mathrm{KCl}$. We put $10 \mathrm{~g}$ of air-dry soil in a $50 \mathrm{ml}$ beaker. We used a measuring cylinder to add $25 \mathrm{ml}$ of $1 \mathrm{M} \mathrm{KCl}$ solution and stirred the mixture well. After 30 minutes (with occasional stirring), the $\mathrm{pH}$ was measured by immersing the double-junction electrode in the suspension [19].

\subsection{Determining soil humus content}

Humus content was determined using the standard Kotzmann method. We weighed out $200 \mathrm{mg}$ of finely ground, air-dried soil on the analytical balance and quantitatively transferred the volume to a dry Erlenmeyer flask. Then, we added $130 \mathrm{ml}$ of distilled water into the beakers, where eventually small-sized particles of soil were rinsed from the interior 
walls of the Erlenmeyer flask and added $20 \mathrm{ml}$ of $\mathrm{H}_{2} \mathrm{SO}_{4}(1: 3)$. Finally, we added $50 \mathrm{ml}$ of $0.1 \mathrm{M} \mathrm{KMnO}_{4}$ from the burette. We placed a small funnel on the Erlenmeyer flask, in order to prevent the liquid from draining. Afterward, we placed the Erlenmeyer flask on the stove, wrote down the boiling time and controlled the process of silent boiling at a time interval of 15 minutes.

The solution was then titrated with $0.1 \mathrm{M}$ oxalic acid solution. Oxalic acid was added until the liquid in the Erlenmeyer flask became colourless. The discoloration was gradual and, therefore, we added an excess of oxalic acid which was titrated again with the $\mathrm{KMnO}_{4}$ solution until the colour became permanent light purple [19].

\subsection{Determination of total nitrogen in the soil}

The Kjeldahl method was used to determine the nitrogen content in the soil. We weighed out $2 \mathrm{~g}$ of finely ground air-dry soil sample and transferred this content to a dry Kjeldahl balloon. A catalyst mixture was added. The contents of the balloon were well stirred, and $25 \mathrm{ml}$ of concentrated sulfuric acid was added. The solution was lightly stirred so that the entire soil sample came in contact with sulfuric acid and, finally, left to stand for 10-15 minutes. The balloon was slightly heated for about 15 minutes and then heated to boiling. Heating continued until the contents of the balloon were discoloured. The balloon was then cooled and an additional $150 \mathrm{ml}$ of water was added.

A $300 \mathrm{ml}$ Erlenmeyer flask of $0.1 \mathrm{ml} \mathrm{HCl}$ and an indicator were placed under the condenser in the distillation apparatus so that the tip of the condenser was immersed in this mixture. Then, $40 \%$ of $\mathrm{NaOH}$ was added cautiously over the funnel by shaking the Kjeldahl balloon. The next phase involved the start of distillation by introducing water vapour into the distillation balloon. Under high-temperature conditions, the ammonium hydroxide decomposed into ammonia and water. The resulting ammonia condensed and passed, drop by drop, into the $\mathrm{HCl}$ solution and the indicator, as it passed through the condenser. When the volume of the distillate reached $120 \mathrm{ml}$, the Erlenmeyer flask containing the acid was put in a lower position and the distillation continued until the total volume of the distillate was about $150 \mathrm{ml}$. Titration of $0.1 \mathrm{~N} \mathrm{HCl}$ solution was performed until the colour changed from green to red $[20,21]$.

\subsection{Determination of available phosphorus and potassium in soil}

For the determination of available phosphorus and potassium in the soil, the AL-EgnerRiehm method was used. The amount of readily available phosphorus and potassium was determined by extraction with a mixture of $0.1 \mathrm{M}$ acetic acid, $0.1 \mathrm{M}$ lactic acid and $0.1 \mathrm{M}$ ammonium acetate, the $\mathrm{pH}$ of the extraction solution is 3.7 . We weighed out $2.5 \mathrm{~g}$ of the sample dissolved in $50 \mathrm{ml}$ of solution. After $2.5 \mathrm{~h}$ of shaking with a rotary shaker, the suspension was filtered through filter paper. From the filtrate, the amount of phosphorus was determined spectrophotometrically (at $\lambda=580 \mathrm{~nm}$, with molybdenum sulfuric acid, tin(II)-chloride and ascorbic acid, as colorants for the solution). The flame photometric determination of potassium was used. Instrument calibration was done with a series of standard solutions [20]. 


\subsection{Determining carbonates in soil}

The determination of the carbonate content in the soil is a volumetric determination on a Scheibler calcimeter.

We weighed $5 \mathrm{~g}$ of soil and transferred to a bottle. A hydrochloric acid tube (1:3) is then placed in the bottle. By moving the pipe, the level was adjusted to "0" of another pipe. During this time, the valve was placed in such a position that the third tube was in contact with the outside environment. The bottle was then sealed tightly with a rubber stopper and turned into a position connecting the other two tubes. The bottle is turned so that the hydrochloric acid from the test tube slowly overflows the soil. The developed gas, $\mathrm{CO}_{2}$, pushes the water in another pipe. By moving the first pipe, the levels of the first and the second pipes were equalized. 15 minutes after the level of liquid was equalized in the first two tubes, the volume of $\mathrm{CO}_{2}$ in the second tube, the pressure on the barometer and the temperature on the thermometer were read [19].

\subsection{Determination of heavy metals in soil}

We weighed $1 \mathrm{~g}$ of dried and finely ground soil sample. The sample was annealed at 500 ${ }^{\circ} \mathrm{C}$ for 3 hours. After cooling, the rest of the sample was quenched with 1-2 ml of distilled water and $1 \mathrm{ml}$ of concentrated $\mathrm{H}_{2} \mathrm{SO}_{4}$ and $20 \mathrm{ml}$ of $\mathrm{HF}$ acid were added. Then, gentle heating was carried out to $120{ }^{\circ} \mathrm{C}$ on the hot plate. After cooling, the solution was well blended, filtered through Whatman 40 filter paper and supplemented with distilled water. The metal content was determined using an atomic absorption spectrophotometer - AAS, PerkinElmer 1100 [22].

\subsection{Determination of heavy metals in plants}

A soil sample $(5 \mathrm{~g})$ was measured in a glass beaker $(50 \mathrm{ml})$. It was gradually burned on the stove (1,2-30 $\mathrm{min}$; 3,4-30 $\mathrm{min}$; and 5,6-30 $\mathrm{min})$ and then transferred to an annealing furnace at $450{ }^{\circ} \mathrm{C}$ from 6 to $12 \mathrm{~h}$.

The sample was extracted from the furnace, cooled and treated with a few drops of deionized water and, if necessary, a few drops of concentrated $\mathrm{HNO}_{3}$, placed on a hot plate (included in the unit) and it carefully evaporates to dryness. It was then gradually amplified, to six (60 min) and put in the oven at $450{ }^{\circ} \mathrm{C}$ for about 60 minutes. The process could have been repeated. If a well-mineralized residue (light to white) was obtained after the first annealing, there would be no need to treat it with deionized water and acid.

After annealing, the residue was further treated with concentrated $\mathrm{HCl}(1-2 \mathrm{ml})$ and then evaporated in a water bath or on a unit rack to dryness (the volume of concentrated $\mathrm{HCl}$ used depends on the removal of the residue - more acid is needed). $5 \mathrm{ml}$ of $10 \% \mathrm{HCl}$ was added to the beaker and warmed slightly, then filtered and quantitatively transferred to a $10 \mathrm{ml}$ normal vessel. The metal content was determined using an atomic absorption spectrophotometer AAS, Perkin-Elmer 1100 [22,23]. 


\section{RESULTS AND DISCUSSION}

Sampling and analysis of the material were performed in two periods:

In 2005, heavy metal contents of $\mathrm{Pb}, \mathrm{Cd}, \mathrm{Cr}, \mathrm{Cu}, \mathrm{Mn}, \mathrm{Zn}$ and $\mathrm{Ni}$ were tested in tobacco of the first and the third harvest in soil from three localities: agricultural district of the village of Ćukovac, agricultural district of the village of Neradovac and agricultural district of the village of Surdul. In the same year, a chemical analysis from the aspect of basic soil fertility parameters $(\mathrm{pH}$ value, humus content, calcium carbonate content, total nitrogen content, readily available phosphorus and potassium in the soil) was made.

In 2018, a survey was conducted and the soil from the same localities for heavy metals $\mathrm{Pb}, \mathrm{Cd}, \mathrm{Cr}, \mathrm{Cu}, \mathrm{Mn}, \mathrm{Zn}$ and $\mathrm{Ni}$ was analyzed. Also, basic soil fertility parameters ( $\mathrm{pH}$ value, humus content, calcium carbonate content, total nitrogen content, readily available phosphorus and potassium in soil) were tested.

\subsection{Soil-test results of heavy metals concentration in tobacco and soil sampled in 2005}

The results of testing the concentration of heavy metals in tobacco samples from 2005 are presented in Table 1.

Based on the obtained values of heavy metal concentrations in tobacco from Ćukovac, it has been observed that the concentrations of heavy metals vary between the first and the third harvest (Table 1). Heavy metal concentration is highest in tobacco leaves of the first harvest.

Table 1 Concentration of heavy metals in tobacco from the agricultural districts of Ćukovac, Neradovac and Surdul village, sampled in 2005

\begin{tabular}{lccccccc}
\hline & \multicolumn{7}{c}{ Heavy metals } \\
\cline { 2 - 8 } & $\begin{array}{c}\mathrm{Pb} \\
(\mathrm{mg} / \mathrm{kg})\end{array}$ & $\begin{array}{c}\mathrm{Cd} \\
(\mathrm{mg} / \mathrm{kg})\end{array}$ & $\begin{array}{c}\mathrm{Cr} \\
(\mathrm{mg} / \mathrm{kg})\end{array}$ & $\begin{array}{c}\mathrm{Cu} \\
(\mathrm{mg} / \mathrm{kg})\end{array}$ & $\begin{array}{c}\mathrm{Mn} \\
(\mathrm{mg} / \mathrm{kg})\end{array}$ & $\begin{array}{c}\mathrm{Zn} \\
(\mathrm{mg} / \mathrm{kg})\end{array}$ & $\begin{array}{c}\mathrm{Ni} \\
(\mathrm{mg} / \mathrm{kg})\end{array}$ \\
\hline Location & $<2.00$ & 3.60 & 1.87 & 13.59 & 41.61 & 3.93 & 2.22 \\
Ćukovac, harvest 1 & $<2.00$ & 1.40 & 1.00 & 6.87 & 33.21 & 2.18 & 1.05 \\
Neradovac, harvest 3 & $<2.00$ & 3.70 & 2.50 & 21.09 & 60.36 & 3.58 & 4.21 \\
Neradovac, harvest 1 & $<2.00$ & 2.40 & 1.00 & 25.62 & 45.00 & 3.62 & 7.89 \\
Surdul, harvest 1 3 & $<2.00$ & 3.80 & 2.62 & 5.64 & 52.68 & 3.68 & 2.63 \\
Surdul, harvest 3 & $<2.00$ & 0.50 & 1.00 & 7.34 & 20.00 & 2.69 & 0.78 \\
\hline
\end{tabular}

Lead concentrations of the first and third harvest were less than $2 \mathrm{mg} / \mathrm{kg}$ indicating that it was less than the toxic concentration for $\mathrm{Pb}$ (toxic concentration for $\mathrm{Pb}$ was up to $20 \mathrm{mg} / \mathrm{kg}$ dry weight); the concentration of $\mathrm{Cd}$ in tobacco leaves of the first harvest was also lower than the toxic concentration for $\mathrm{Cd}$ which was up to $10 \mathrm{mg} / \mathrm{kg}$ of dry weight; the concentrations of $\mathrm{Cr}$ in tobacco leaves from this locality were $1.87 \mathrm{mg} / \mathrm{kg}$ for the first harvest, $3.00 \mathrm{mg} / \mathrm{kg}$ for the third harvest, which was lower than the toxic $\mathrm{Cr}$ concentration of $2 \mathrm{mg} / \mathrm{kg}$ of dry weight. The concentration of $\mathrm{Cu}$ at $13.59 \mathrm{mg} / \mathrm{kg}$ and $6.87 \mathrm{mg} / \mathrm{kg}$ in the first and third harvest, respectively, was also lower than the toxic concentration for $\mathrm{Cu}$ which was $20 \mathrm{mg} / \mathrm{kg}$ of dry weight. Mn was represented by 41.61 $\mathrm{mg} / \mathrm{kg}$ in tobacco leaves of the first harvest, $33.21 \mathrm{mg} / \mathrm{kg}$ at third harvest, which was much lower than the toxic concentration for $\mathrm{M}$ of $400 \mathrm{mg} / \mathrm{kg}$ dry weight, while $\mathrm{Zn}$ 
concentrations of $3.93 \mathrm{mg} / \mathrm{kg}$ and $2.18 \mathrm{mg} / \mathrm{kg}$, were below the toxic concentration for $\mathrm{Zn}$ $(200 \mathrm{mg} / \mathrm{kg}$ of dry weight). The toxic concentration for $\mathrm{Ni}$ of $30 \mathrm{mg} / \mathrm{kg}$ of dry weight exceeded the measured values for this metal $(2.22 \mathrm{mg} / \mathrm{kg} ; 1.05 \mathrm{mg} / \mathrm{kg})$.

Based on the results of tobacco analysis from the location of Cukovac, it can be concluded that the concentrations of the heavy metals in the tobacco leaves are significantly lower than the toxic concentrations for the cultivated plants.

By comparing the concentrations of heavy metals in tobacco from Neradovac village, it can be seen that the presence of heavy metals in the leaves of the first tobacco harvest is higher. The exceptions are copper, zinc and nickel. The copper content in the samples of the first tobacco harvest was $21.09 \mathrm{mg} / \mathrm{kg}$, whereas in the samples of the third harvest it was $25.62 \mathrm{mg} / \mathrm{kg}$. The zinc content in the first harvest was $3.58 \mathrm{mg} / \mathrm{kg}$, and in the third, it was $3.62 \mathrm{mg} / \mathrm{kg}$, while the nickel content in the first harvest was $4.21 \mathrm{mg} / \mathrm{kg}$ and in the third, it was $7.89 \mathrm{mg} / \mathrm{kg}$ (Table 1)

$\mathrm{Pb}$ concentrations in tobacco leaves of the first and the third harvest were $<2 \mathrm{mg} / \mathrm{kg}$, which was significantly lower than the toxic concentration for $\mathrm{Pb}, 20 \mathrm{mg} / \mathrm{kg}$ dry weight. The concentrations of $\mathrm{Cd}$ detected in tobacco leaves from this location (first harvest -3.70 $\mathrm{mg} / \mathrm{kg}$, third harvest $-2.40 \mathrm{mg} / \mathrm{kg}$ ) indicated Cd values below the toxic ones $(10 \mathrm{mg} / \mathrm{kg}$ dry weight). The toxic concentration of chrome in cultivated plants with $2 \mathrm{mg} / \mathrm{kg}$ of dry weight was slightly exceeded in the samples collected at the first harvest of tobacco leaves in the agricultural district of Neradovac village. The concentrations of $\mathrm{Cu}$ in the tobacco of this locality were $21.09 \mathrm{mg} / \mathrm{kg}$ and $25.62 \mathrm{mg} / \mathrm{kg}$, respectively, for the first and the third harvests, respectively, indicating a slightly higher concentration of $\mathrm{Cu}$ in both harvests, relative to the toxic concentration of $20 \mathrm{mg} / \mathrm{kg}$ dry weight. The concentration of $\mathrm{Mn}$ in tobacco leaves from the first harvest was well below the toxic concentration of $\mathrm{Mn}(400 \mathrm{mg} / \mathrm{kg}$ dry weight). Also, the $\mathrm{Zn}$ concentration in both harvests was well below the toxic $\mathrm{Zn}$ concentration, which was $200 \mathrm{mg} / \mathrm{kg}$ dry weight. The Ni concentration in the first harvest of tobacco was $4.21 \mathrm{mg} / \mathrm{kg}$ and in the third harvest it was $7.89 \mathrm{mg} / \mathrm{kg}$; in both cases, it was lower than the toxic concentration for $\mathrm{Ni}, 30 \mathrm{mg} / \mathrm{kg}$ of dry weight.

The results of examed heavy metal concentrations in tobacco leaves from Neradovac in most cases indicate that heavy metal concentrations are lower than the toxic concentrations in the case of cultivated plants. An exception is $\mathrm{Cr}$ and $\mathrm{Cu}$ concentrations which are slightly higher than the toxic concentrations of these metals.

The concentrations of heavy metals in tobacco from the location of Surdul, for the majority of heavy metals, indicated higher amounts in the first harvest (Table 1). The exception was copper $(5.46 \mathrm{mg} / \mathrm{kg}$ in the first harvest, $7.34 \mathrm{mg} / \mathrm{kg}$ in the third harvest).

The analysis of the results in Table 1, which shows the heavy metal concentrations at the location of Surdul, indicates the lower values in tobacco leaves from the first and the third harvest than those in Ćukovac and Neradovac. The concentrations of $\mathrm{Pb}$ during the first and the third harvest were less than $2 \mathrm{mg} / \mathrm{kg}$, which was below the toxic concentration for $\mathrm{Pb}$ of $20 \mathrm{mg} / \mathrm{kg}$ dry weight. The concentration of $\mathrm{Cd}$ in leaves during the first harvest was 3.80 $\mathrm{mg} / \mathrm{kg}$ and in the third harvest, it was $0.50 \mathrm{mg} / \mathrm{kg}$, which was lower than the toxic concentration of $\mathrm{Cd}$, which is $10 \mathrm{mg} / \mathrm{kg}$ dry weight. The concentration of $\mathrm{Cr}$ in tobacco leaves during the first harvest was $2.62 \mathrm{mg} / \mathrm{kg}$, and during the third harvest, it was 1.00 $\mathrm{mg} / \mathrm{kg}$. The concentration from the first harvest was slightly higher than the toxic concentration of $\mathrm{Cr}$, which was $2 \mathrm{mg} / \mathrm{kg}$ dry weight. The concentration of $\mathrm{Cu}$ in the first harvest was $5.64 \mathrm{mg} / \mathrm{kg}$, and in the third, it was $7.34 \mathrm{mg} / \mathrm{kg}$ (lower than the toxic 
concentration of $\mathrm{Cu}$ which is $20 \mathrm{mg} / \mathrm{kg}$ dry weight). The concentration of $\mathrm{Mn}$ in the first harvest was $52.68 \mathrm{mg} / \mathrm{kg}$, in the third harvest it was $20.00 \mathrm{mg} / \mathrm{kg}$ (toxic concentration for Mn was $400 \mathrm{mg} / \mathrm{kg}$ of dry matter). Zn concentrations, which were $3.68 \mathrm{mg} / \mathrm{kg}$ and 2.69 $\mathrm{mg} / \mathrm{kg}$ respectively, did not exceed the toxic concentrations for $\mathrm{Zn}$ (200 mg/kg dry weight), which was also observed in the case of $\mathrm{Ni}(2.63 \mathrm{mg} / \mathrm{kg}$ - first harvest; $0.78 \mathrm{mg} / \mathrm{kg}$ - third harvest; $30 \mathrm{mg} / \mathrm{kg}$ - toxic concentration).

Since Surdul village is located at a greater distance from Vranje, it can be used as a control location, and the results of heavy metal concentrations in this site indicate the lower values compared to the previous two locations. This can be related to the distance from the roads and the reduced volume of agricultural production, and consequently, the reduced use of agrochemicals that contain heavy metals. In addition, the higher concentrations of heavy metals found in tobacco at the locations of Ćukovac and Neradovac sites can be justified by the proximity of the main road and local asphalt roads, although in many cases these values of heavy metals were lower than the toxic concentrations in cultivated plants.

Table 2 Concentration of heavy metals in the soil of examined locations, agricultural districts of Ćukovac, Neradovac, Surdul, sampled in 2005

\begin{tabular}{|c|c|c|c|c|c|c|c|}
\hline \multirow[b]{2}{*}{ Locations } & \multicolumn{7}{|c|}{ Heavy metals } \\
\hline & $\begin{array}{c}\mathrm{Pb} \\
(\mathrm{mg} / \mathrm{kg})\end{array}$ & $\begin{array}{c}\mathrm{Cd} \\
(\mathrm{mg} / \mathrm{kg})\end{array}$ & $\begin{array}{c}\mathrm{Cr} \\
(\mathrm{mg} / \mathrm{kg})\end{array}$ & $\begin{array}{c}\mathrm{Cu} \\
(\mathrm{mg} / \mathrm{kg})\end{array}$ & $\begin{array}{c}\mathrm{Mn} \\
(\mathrm{mg} / \mathrm{kg})\end{array}$ & $\begin{array}{c}\mathrm{Zn} \\
(\mathrm{mg} / \mathrm{kg})\end{array}$ & $\begin{array}{c}\mathrm{Ni} \\
(\mathrm{mg} / \mathrm{kg})\end{array}$ \\
\hline Ćukovac & $<10.00$ & $<1.00$ & 99.75 & 56.25 & 193.30 & 20.90 & 62.50 \\
\hline Neradovac & $<10.00$ & $<1.00$ & 67.50 & 33.60 & 105.80 & 20.60 & $<2.00$ \\
\hline Surdul & $<10.00$ & $<1.00$ & 70.00 & 35.90 & 96.00 & 21.00 & $<2.00$ \\
\hline
\end{tabular}

The concentrations of heavy metals in the soil of the analyzed locations revealed some discrepancies. A slightly higher concentration of chromium, copper, manganese, and nickel was found in soil from Ćukovac village, while the lowest concentrations in the majority of examined heavy metals were found in soil around Neradovac (Table 2).

The results about heavy metal concentrations in the soil of the examined sites indicated that the concentrations of all examined heavy metals in soil were lower than the maximum allowed (except for $\mathrm{Ni}$ at the location of Ćukovac village) concentrations of dangerous and harmful substances in the soil [24]. By comparing the obtained results with the threshold limit values and the remediation values [25], it can be concluded that:

- the concentrations of $\mathrm{Pb}, \mathrm{Zn}$ and $\mathrm{Cr}$ in all analyzed samples do not exceed the threshold limit values, nor remediation values for these metals;

- the concentration of $\mathrm{Cd}$ in all analyzed samples is less than $1.00 \mathrm{mg} / \mathrm{kg}$ which is the upper limit in comparison to the threshold limit values $(0.80 \mathrm{mg} / \mathrm{kg})$, and is significantly below threshold limit value $(12.00 \mathrm{mg} / \mathrm{kg})$;

- the concentration of $\mathrm{Cu}$ is $56.25 \mathrm{mg} / \mathrm{kg}$ (the location of Ćukovac) which exceeds threshold limit value $(36.00 \mathrm{mg} / \mathrm{kg}$ ) but not the remediation value $(190.00 \mathrm{mg} / \mathrm{kg})$, while the concentrations of $\mathrm{Cu}$ at other locations are below threshold limit and remediation values;

- the concentration of $\mathrm{Ni}$ from the location of Cukovac $(62.52 \mathrm{mg} / \mathrm{kg})$ is above the threshold limit values $(35.00 \mathrm{mg} / \mathrm{kg})$ but not above the remediation value $(210.00$ $\mathrm{mg} / \mathrm{kg}$ ). The concentration of $\mathrm{Ni}$ in the samples of other locations (lower than 2 $\mathrm{mg} / \mathrm{kg}$ ) is far below the threshold limit and remediation values. 


\subsection{Soil-test results of basic fertility parameters sampled in 2005}

The results of testing basic soil fertility parameters sampled in 2005 at the villages of Ćukovac, Neradovac and Surdul show that the $\mathrm{pH}$ ranges from 5.10 to $7.20 . \mathrm{CaCO}_{3}$ content ranges from 0.00 to $1.50 \%$; humus from $1.77 \%$ (Ćukovac) to $3.05 \%$ (Surdul); total nitrogen from $0.09 \%$ (Ćukovac) to $0.15 \%$ (Surdul); readily available phosphorus, expressed as mg of $\mathrm{P}_{2} \mathrm{O}_{5}$ in $100 \mathrm{~g}$ of soil, from $11.00 \%$ (Surdul) to $13.00 \%$ (Neradovac); readily available potassium, expressed as $\mathrm{mg} \mathrm{K}_{2} \mathrm{O}$ in $100 \mathrm{~g}$ of soil, from $20.50 \%$ (Surdul) to $27.00 \%$ (Ćukovac). (Table 3)

Table 3 Basic parameters of soil fertility from the locations of Ćukovac, Neradovac, Surdul, sampled in 2005

\begin{tabular}{lccccccc}
\hline & \multicolumn{7}{c}{ Parameters of soil fertility } \\
\cline { 2 - 8 } & & & & & $\begin{array}{c}\mathrm{mg} \\
\mathrm{P}_{2} \mathrm{O}_{5} / 100 \mathrm{~g} \\
\text { soil }\end{array}$ & $\begin{array}{c}\mathrm{mg} \\
\mathrm{K}_{2} \mathrm{O} / 100 \mathrm{~g} \\
\text { soil }\end{array}$ & $\%$ \\
Location & $\mathrm{H}_{2} \mathrm{O}$ & $\mathrm{KCl}$ & $\%$ & $\%$ & $\mathrm{P}$ & $\mathrm{K}$ & $\mathrm{CaCO}_{3}$ \\
\cline { 3 - 8 } & & & Humus & $\mathrm{N}$ & 12.00 & 27.00 & 1.50 \\
Ćukovac & 7.20 & 7.10 & 1.77 & 0.09 & 13.00 & 24.00 & 0.00 \\
Neradovac & 5.30 & 5.10 & 1.92 & 0.10 & 11.00 & 20.50 & 0.00 \\
\hline
\end{tabular}

Analyzing the test results of the chemical composition of soil in the examined locations, as shown in Table 3, it can be seen that the soil $\mathrm{pH}$ at all three localities ranged from acidic (5.10) to neutral (7.20). Based on the $\mathrm{pH}$ value in this research, it can be determined as follows: the soil in Ćukovac $(\mathrm{pH} 7.10 ; 7.20)$ is neutral, while the soils in Neradovac (pH 5.10; 5.30) and Surdul (pH 5.45; 5.50) are acidic [19].

The amount of humus in the soils of the examined locations ranged from $1.77 \%$ to $3.05 \%$. These values indicate that the soil in Ćukovac village has relatively low humus content $(1.77 \%)$, the soil in the location of Neradovac village $(1.92 \%)$ which is also low humus content, while the soil around Surdul village has higher humus content $(3.05 \%)$. Following the classification of soils by their humus content (Scheffer-Schachtschabel classification), these soils are low-humic and mediate-humic [19].

Phosphorus content in the soil of the examined locations is relatively the same; the location of Ćukovac 12.00, the location of Neradovac 13.00 and the location of Surdul $11.00 \mathrm{mg} \mathrm{P}_{2} \mathrm{O}_{5} / 100 \mathrm{~g}$ of soil. All examined soils have medium content of phosphorus (containing between 10 and $20 \mathrm{mg} \mathrm{P}_{2} \mathrm{O}_{5} / 100 \mathrm{~g}$ of soil) [20].

The content of $\mathrm{K}_{2} \mathrm{O}$ in the surveyed locations is as follows: Ćukovac 27.00, Neradovac 24.00 and Surdul 20.50, which indicates that the soils in these locations are rich in this nutrient [20].

$\mathrm{CaCO}_{3}$ in soil has an impact on the reaction of soil and thus creates conditions for mineralization of organic substances. The soil of the Ćukovac village contained $1.50 \%$, while no significant amounts of carbonate were detected in the soil of Neradovac and Surdul villages. It can be concluded that the soil in Ćukovac is poor in carbonate $(0.10$ $2.00 \%)$, while the soil of Neradovac and Surdul are carbonless $(0.00 \%)$ [19].

The percentage of nitrogen in the soil of examined locations was: Ćukovac $0.09 \%$, Neradovac $0.10 \%$ and Surdul $0.15 \%$. Based on nitrogen content, in line with threshold 
limit values of nitrogen by Wohltmann, the soil in Ćukovac is medium rich in nitrogen content $(0.06-0.10 \%)$ and the soil in the locations of Neradovac and Surdul are rich in nitrogen content $(0.10-0.02 \%)$ [20].

\subsection{Test results for heavy metals concentration in soil sampled in 2018}

The results of testing heavy metals in the soil of agricultural parcels at the locations of Ćukovac, Neradovac and Surdul are shown in Table 4.

Table 4 The concentration of heavy metals in the soil of the examined locations, agricultural districts of Ćukovac, Neradovac and Surdul, sampled in 2018.

\begin{tabular}{lccccccc}
\hline & \multicolumn{7}{c}{ Heavy metals } \\
\cline { 2 - 8 } & $\begin{array}{c}\mathrm{Pb} \\
\text { Location }\end{array}$ & $\begin{array}{c}\mathrm{Cd} \\
(\mathrm{mg} / \mathrm{kg})\end{array}$ & $\begin{array}{c}\mathrm{Cr} \\
(\mathrm{mg} / \mathrm{kg})\end{array}$ & $\begin{array}{c}\mathrm{Cu} \\
(\mathrm{mg} / \mathrm{kg})\end{array}$ & $\begin{array}{c}\mathrm{Mn} \\
(\mathrm{mg} / \mathrm{kg})\end{array}$ & $\begin{array}{c}\mathrm{Zn} \\
(\mathrm{mg} / \mathrm{kg})\end{array}$ & $\begin{array}{c}\mathrm{Ni} \\
(\mathrm{mg} / \mathrm{kg})\end{array}$ \\
\hline Ćukovac & 50.40 & $<0.50$ & 38.40 & 35.40 & 605.00 & 78.90 & 36.20 \\
Neradovac & 12.30 & $<0.50$ & 27.30 & 21.20 & 284.00 & 44.10 & 26.70 \\
Surdul & 8.40 & $<0.50$ & 16.40 & 15.40 & 220.00 & 32.50 & 15.10 \\
\hline
\end{tabular}

By analyzing the data in Table 4, it can be seen that the concentrations of certain heavy metals from the same locations sampled in 2005 were higher than those in the 2018 samples.

The concentrations of $\mathrm{Pb}$ in soil were lower than $10 \mathrm{mg} / \mathrm{kg}$ at all three locations examined in 2005 , while the concentrations at Ćukovac $(50.40 \mathrm{mg} / \mathrm{kg})$ and Neradovac $(12.30 \mathrm{mg} / \mathrm{kg})$ increased in 2018, respectively. However, at the location of Surdul, which was at the same time the control location, $\mathrm{Pb}$ concentration in soil in 2018 was less than $10 \mathrm{mg} / \mathrm{kg}$ (more exactly, it was $8.40 \mathrm{mg} / \mathrm{kg}$ ). The increased $\mathrm{Pb}$ concentrations at Ćukovac and Neradovac locations are likely to be of anthropogenic origin since both locations are adjacent to the asphalt local roads and close to the E-75 highway. However, although the $\mathrm{Pb}$ concentration is increased in the samples from these two locations, it does not exceed the MAC for $\mathrm{Pb}$.

The Cd concentration at the tested locations in 2005 was less than $1.00 \mathrm{mg} / \mathrm{kg}$, while repeated analyses in 2018 showed a lower $\mathrm{Cd}$ concentration at all three locations $(0.50$ $\mathrm{mg} / \mathrm{kg}$ ), which also did not exceed the MAC for $\mathrm{Cd}$.

Comparing the presence of $\mathrm{Cr}$ in the soil samples of the surveyed localities in 2005 with the results from the 2018 samples, there is a noticeable decrease in the $\mathrm{Cr}$ concentration in the 2018 soil samples. Cr concentrations in 2005 at the tested locations ranged from $70.00 \mathrm{mg} / \mathrm{kg}$ to $99.75 \mathrm{mg} / \mathrm{kg}$, while new analyses of the same locations in 2018 showed values of $16.40 \mathrm{mg} / \mathrm{kg}$ (Surdul), then $27.30 \mathrm{mg} / \mathrm{kg}$ (Neradovac) and 38.40 $\mathrm{mg} / \mathrm{kg}$ (Ćukovac), which is below the MAC for $\mathrm{Cr}$.

The analysis of the obtained concentrations of $\mathrm{Cu}$ in the soil of the examined locations in 2005 and 2018, respectively, are also different. In 2005, the concentrations ranged from $35.90 \mathrm{mg} / \mathrm{kg}$ to $56.25 \mathrm{mg} / \mathrm{kg}$, while in 2018 the concentrations of $\mathrm{Cu}$ at all three locations were much lower - Ćukovac $35.40 \mathrm{mg} / \mathrm{kg}$, Neradovac $21.20 \mathrm{mg} / \mathrm{kg}$ and Surdul $15.40 \mathrm{mg} / \mathrm{kg}$ (the concentrations are significantly lower than MAC for $\mathrm{Cu}$ ).

There is a significant difference in the concentration of $\mathrm{Mn}$ in the study areas in 2005 and 2018, respectively. The concentrations of $\mathrm{Mn}$ in 2018 at the examined locations were higher than in 2005, and are probably derived from the parent substrate.

The concentrations of $\mathrm{Zn}$ were to a certain extent higher in the samples taken in 2018. Therefore, the results are as follows: Ćukovac in 2018 (78.90 mg/kg), in 2005 (20.90 mg/kg); 
Neradovac in $2018(44.10 \mathrm{mg} / \mathrm{kg})$, in $2005(20,60 \mathrm{mg} / \mathrm{kg})$ and Surdul in 2018. $(32.50 \mathrm{mg} / \mathrm{kg})$, in $2005(21.00 \mathrm{mg} / \mathrm{kg})$.

Despite the increased $\mathrm{Zn}$ concentration in the soil at all three locations, these concentrations are still below the MAC for $\mathrm{Zn}$.

The content of $\mathrm{Ni}$ in the examined locations was higher in 2005 than in 2018, in the case of Ćukovac - in $2005(62.50 \mathrm{mg} / \mathrm{kg})$, in $2018(36.20 \mathrm{mg} / \mathrm{kg})$. However, in other two locations the $\mathrm{Ni}$ content was lower in 2005, namely - Neradovac in 2005 (less than $2 \mathrm{mg} / \mathrm{kg}$ ), in 2018 (26.70 mg/kg), and Surdul in 2005 (less than $2 \mathrm{mg} / \mathrm{kg})$, in $2018(15.10 \mathrm{mg} / \mathrm{kg})$.

By comparing the results with the threshold limit values, as well as with the remediation values [25], it can be concluded that all measured values are below the limit values and remediation values.

\subsection{Soil-test results of basic soil fertility parameters sampled in 2018}

The results of the examination of the chemical composition of the soil samples from 2018 at the locations of Ćukovac, Neradovac and Surdul show that the soil $\mathrm{pH}$ value in these locations was acidic and slightly acidic $(5.27-6.08)$. Humus content ranged from $3.25 \%$ in the Surdul to $3.01 \%$ in the Ćukovac, which means these soils have moderate content of humus $(2.00-4.00 \%)$. The content of total nitrogen was relatively equal at three locations $0.14 \%-0.16 \%$. In line with threshold limit values of nitrogen by Wohltmann, soils from all analyzed locations are rich in nitrogen $(0.10-0.20 \% \mathrm{~N})$. The phosphorus content in these locations ranged from 12.30 in Surdul (soil is medium rich in phosphorus) to $21.03 \mathrm{mg} \mathrm{P}_{2} \mathrm{O}_{5} / 100 \mathrm{~g}$ soil in Ćukovac (soil is rich in phosphorus). The potassium content ranged from 19.50 in Surdul to $33.46 \mathrm{mg} \mathrm{K}_{2} \mathrm{O} / 100 \mathrm{~g}$ of soil in Neradovac. The carbonate content was negligible in all analyzed samples (Table 5). In comparison to the data obtained from the 2005 soil analysis, there is a slight difference in $\mathrm{pH}$.

Table 5 Basic soil fertility parameters in Ćukovac, Neradovac, Surdul, sampled in 2018

\begin{tabular}{|c|c|c|c|c|c|c|c|}
\hline \multirow{5}{*}{ Location } & \multicolumn{7}{|c|}{ Soil fertility parameters } \\
\hline & \multirow{4}{*}{$\begin{array}{c}\mathrm{pH} \mathrm{u} \\
\mathrm{H}_{2} \mathrm{O}\end{array}$} & \multirow{4}{*}{$\begin{array}{c}\mathrm{pH} \mathrm{u} \\
\mathrm{KCl}\end{array}$} & \multirow{3}{*}{$\%$} & \multirow{3}{*}{$\%$} & \multirow{3}{*}{$\begin{array}{c}\mathrm{mg} \\
\mathrm{P}_{2} \mathrm{O}_{5} / 100 \mathrm{~g} \\
\text { soil }\end{array}$} & \multicolumn{2}{|l|}{$\mathrm{mg}$} \\
\hline & & & & & & $\mathrm{K}_{2} \mathrm{O} / 100 \mathrm{~g}$ & $\%$ \\
\hline & & & & & & soil & \\
\hline & & & Humus & $\mathrm{N}$ & $\mathrm{P}$ & $\mathrm{K}$ & $\mathrm{CaCO}_{3}$ \\
\hline Ćukovac & 6.00 & 6.08 & 3.01 & 0.14 & 21.03 & 32.18 & - \\
\hline Neradovac & 5.80 & 5.73 & 2.83 & 0.14 & 19.66 & 33.46 & - \\
\hline Surdul & 5.50 & 5.27 & 3.25 & 0.16 & 12.30 & 19.50 & - \\
\hline
\end{tabular}

Phosphorus content in the examined plots of land in these villages was higher in repeated examinations than it was in 2005 , which may be attributed to the increased use of artificial fertilizers.

Potassium content in the examined locations in 2018 revealed increased values when compared to 2005 .

The content of $\mathrm{CaCO}_{3}$ in the soil has an impact on the reactions in soil and the mineralization of organic matter. However, in repeated analyzes in 2018, the lands of all three locations were carbonless.

The content of nitrogen in the examined localities in 2018 did not change to a great extent when compared to 2005 , and it ranged from $0.14 \%$ to $0.16 \%$. 


\section{CONCLUSION}

Based on the results of soil-tests of heavy metals in potential locations for tobacco production in Vranje valley, the following conclusions were reached:

The concentration of heavy metals in the soil of agricultural districts of Ćukovac and Neradovac villages sampled in 2005 is higher than the concentration in a control location (Surdul). The reason for higher concentrations of heavy metals at the examined locations is likely to be due to the proximity of the E-75 highway and increased use of artificial fertilizers and pesticides, bearing in mind that agricultural production is more intensive in this part of Vranje valley and almost neglected in the village of Surdul.

In the light of the results of tobacco analysis from the location of Cukovac, it can be concluded that the concentrations of heavy metals in the tobacco leaves are significantly lower than the toxic concentrations for the cultivated plants. The results obtained by testing the concentrations of heavy metals in tobacco leaves from the Neradovac in most cases indicate that their concentrations are lower than the toxic concentrations present in cultivated plants. The exceptions are $\mathrm{Cr}$ and $\mathrm{Cu}$ concentrations which are slightly higher than the toxic concentrations for these metals. Since Surdul is located at a greater distance from Vranje, the results of heavy metal examinations from this location indicate rather lower values than in the case of other locations. This can be attributed to their distance from the roads and the city, reduced agricultural production and, consequently, the use of agrochemicals containing heavy metals. The higher concentrations of heavy metals found in tobacco at the locations of Ćukovac and Neradovac can be justified by the proximity of the main road and local asphalt roads, although in many cases these values of heavy metals were lower than the toxic concentrations for cultivated plants.

Repeated analyses of heavy metals in soils of the same locations carried out in 2018 confirm the assumption that these soils have low concentrations of heavy metals.

The analyzes of soil chemical composition at all three sites in 2005 indicate that their chemical composition is good, especially when it comes to soil $\mathrm{pH}$, the content of $\mathrm{N}, \mathrm{P}$ and $\mathrm{K}$, the presence of carbonates and humus.

Similar results were obtained in 2018, where basic soil chemical parameters also ranged within the limits corresponding to plant growth and development, without any adverse effects.

By comparing the results of the study of soil chemical composition and the presence of heavy metals in 2005 with the results of the same parameters in 2018 at the locations of Cukovac, Neradovac and Surdul, it can be concluded that the values obtained are below the maximum allowed and remediation values. Because the remediation values of pollutants and hazardous substances in the soil are those values, which, if exceeded degrade the level of safety, it can be concluded that these values were exceeded in neither of the analyzed samples and that the soils are potentially safe to use with the additional tests as well as with the necessary limitations in operating mode.

Acknowledgment: This research was supported by the Ministry of Education, Science and Technological Development of the Republic of Serbia. 


\section{REFERENCES}

1. Ministry of Environment, Republic of Serbia: Land Status Report for the Republic of Serbia 2016-2017, Belgrade, Environmental Protection Agency, 2018.

2. Marković M., Cupać S., Đurović R., Milinović J. and Kljajić P.: Assessment of Heavy Metal and Pesticide Levels in Soil and Plant Products from Agricultural Area of Belgrade, Serbia, Arch. Environ. Contam. Toxicol., Vol. 58, pp. 341-351, 2010.

3. Vašíčkova J., Hvezdova M., Kosubova P. and Hofman J.: Ecological risk assessment of pesticide residues in arable soils of the Czech Republic, Chemosphere, Vol. 216, pp. 479-487, 2019.

4. Bhandaria G., Atreya K., Scheepers P. and Geissena V.: Concentration and distribution of pesticide residues in soil: Non-dietary human health risk assessment, Chemosphere, Vol. 253, pp 126594, 2020.

5. Wuana R. and Okieimen F.: Heavy Metals in Contaminated Soils: A Review of Sources, Chemistry, Risks and Best Available Strategies for Remediation, International Scholarly Research Network., Vol. 2011, pp. 1-20, 2011.

6. Arsić M.: Chemical properties of soil as a basis for the production of plant crops in the region of Vranje, Knowledge - International Journal, Vol. 28.4, pp. 1277 -1279, 2018

7. Bozhinova R.: Heavy metal concentrations in soil and tobacco plants following long-term phosphorus fertilization, Bulgarian Journal of Agricultural Science, Vol. 22, pp. 16-20, 2016.

8. Akpinar C.: Effect of $\mathrm{Zn}$ and $\mathrm{Cd}$ application on wheat growth and mineral nutrients concentration, Fresenius Environmental Bulletin, Vol. 28, pp. 410-415, 2019.

9. Pivic R,, Stanojkovic-Sebic A., Josic D. and Dinic Z.: Evaluation of the heavy metals content in soil and plant material at different distances from the motorway E75 in the section Belgrade-Presevo (Serbia), Bulgarian Journal of Agricultural Science, Vol. 20, pp. 330-336, 2014.

10. Vasin J., Petrović P., Banjac D., Živanov M. and Ninkov J.: Soil quality testing for tobacco production in regions of Vojvodina and Mačva, Sustainable land management, Proceedings, Rimski Šančevi, Serbia, September 10, 2015, pp. 115-121, 2015.

11. Oren M. and Alemdar T.: Technical efficiency analysis of tobacco farming in Southeastern Anatolia, Turk. J. Agric. Fo., Vol. 30, pp. 165-172, 2006.

12. Zaprjanova P.P., Dospatliev.L., Angelova V. and Ivanov K.: Correlation between soil characteristics and lead and cadmium content in the aboveground biomass of Virginia tobacco, Environ. Monit. Assess., Vol. 163 , pp. 253-261, 2010.

13. Jordanoska B., Stafilov T. and Pelivanoska V.: Accumulation and availability of trace elements from the soil into oriental tobacco grown in Macedonia, Environmental Engineering and Management Journal, Vol. 17, pp. 1491-1500, 2018.

14. Mengling Y., Dan Z., Hao J. and Hui Q.: Heavy metals contents and risk assessment of tobacco soil on the edge of Sichuan Basin, J. Drug. Discov. Develop. and Deliv., Vol. 4, pp. 1-4, 2017.

15. Regassa G. and Chandravanshi B. S.: Levels of heavy metals in the raw and processed Ethiopian tobacco leaves, SpringerPlus, Vol. 5, pp. 1-9, 2016.

16. Jovičić Ž.: Prilog geomorfološkim proučavanjima Vranjske kotline i Grdeličke klisure, Vranjski glasnik, Knjiga 4, Narodni muzej u Vranju, Vranje, 1968.

17. Kostić M.: Vranjska Banja, prilog termalnoj geografiji SR Srbije, Vranjski glasnik, Knjiga 5, 1969.

18. Guide to laboratory establishment for plant nutrient analysis, Food and agriculture organization of the United Nations, Rome, Italy, 2008.

19. Belić M., Nešić Lj. and Ćirić V.: D. and Polic P.: Practicum in pedology, University of Novi Sad, Faculty of Agriculture, Novi Sad, 2014.

20. Predić T.: Practicum in Agrochemistry and Plant Nutrition, University of Banja Luka, Faculty of Agriculture and Agricultural Institute, Banja Luka, 2011.

21. https://www.itwreagents.com/uploads/20180114/A173_EN.pdf

22. Arsić M.: Heavy metals in the soil of potential tobacco production locations in Vranje Valley, Master's thesis, University of Niš, Faculty of Occupational Safety in Niš, Niš. 2019.

23. Živković N., Takić Lj., Djordjević Lj., Djordjević A., Mladenović-Ranisavljević I., Golubović T. and Božilov Aca.: Concentrations of heavy metal cations and a health risk assessment of sediments and river surface water: a case study from a Serbian mine, Pol. J. Environ. Stud., Vol. 28, No. 3, pp. 2009-2020, 2019.

24. Official Gazette of RS no. 23/94.

25. Directive on limit values of pollutants, harmful and hazardous substances in soil, Official Gazette of the RS No. 30/2018 and 64/2019. 


\section{TEŠKI METALI U ZEMLJIŠTU POTENCIJALNIH LOKALITETA ZA PROIZVODNJU DUVANA U VRANJSKOJ KOTLINI}

U vranjskoj kotlini je proizvonja duvana bila veoma zastupljena do promene vlasništva Duvanske industrije Vranje. Broj domaćinstava koja se bave uzgojem duvana je znatno opao u poslednjih 15 godina, mada i dalje postoji dobar potencijal u poljoprivrednom zemljištu za uzgoj ove kulture. $S$ obzirom na činjenicu da kvalitet duvana zavisi od uslova pod kojim se uzgaja, pre svega od kvaliteta zemljišta, veoma je značajno poznavati njegov sastav i prisustvo eventualnih zagađujućih supstanci u zemljištu, kao i mehanizme njihovog transfera u biljku. Zagađujuće supstance u poljoprivrednom zemljištu potiču iz prirodnih i antropogenih izvora. Značajni antropogeni izvori zagađujućih supstanci u zemljištu su poljoprivredna proizvodnja (mineralna, organska dubriva i pesticidi), kao i drumski saobraćaj. Jedna od najznačajnijih grupa zagađujućih supstanci s aspekta kvaliteta duvana jesu teški metali. Mineralna, organska đubriva i pesticidi često u svom sastavu sadrže teške metale. Imajući u vidu navedene činjenice cilj ovog rada bio je određivanje i analiza sardžaja teških metala $\mathrm{Pb}, \mathrm{Cd}, \mathrm{Cr}, \mathrm{Cu}$, Mn, Zn i Ni u zemljištu atara sela Neradovac, Ćukovac i Surdul, koji predstavljaju potencijalne lokalitete za proizvodnju duvana. Istraživanja su obuhvatila dva perioda, 2005. i 2018. godinu (analiza zemljišta) i 2005. godinu (analiza duvana). Uporednom analizom rezultata došlo se do zaključaka da su koncentracija teških metala na ispitivanim lokalitetima u zemljištu i duvanu uzorkovanim 2005. godine, kao i koncentracije teških metala u zemljištu uzorkovanom 2018. godine ispod maksimalno dozvoljenih $i$ remedijacionih vrednosti. S obzirom na činjenicu da remedijacione vrednosti zagadujućih, štetnih $i$ opasnih materija u zemljišstu, predstavljaju one vrednosti pri čijem prekoračenju dolazi do narušavanja nivoa koji je bezbedan za korišćenje, može se zaključiti da ni u jednom od analiziranih uzoraka ove vrednosti nisu prekoračene i da su zemljišta potencijalno bezbedna za korišćenje uz dodatna ispitivanja kao $i$ uz potrbna ograničenja u načinu upravljanja. Takođe, hemijski sastav zemljišta navedenih lokaliteta ukazuje da je vrednost ispitivanih parametara u granicama koje odgovaraju rastu i razvoju biljaka bez štetnih posledica, što potvrđuje pretpostavku da su ovi lokaliteti pogodni za proizvodnju duvana.

Ključne reči: teški metali, zemljište, duvan, zagađivanje 